ZOOLOGIA 30 (5): 569-573, October, 2013

http://dx.doi.org/10.1590/S1984-46702013000500009

\title{
The first species of Roquettea from Maranhão, Brazil (Opiliones: Cosmetidae: Discosomaticinae)
}

\begin{abstract}
Adriano B. Kury
Departamento de Invertebrados, Museu Nacional, Universidade Federal do Rio de Janeiro. Quinta da Boa Vista, São Cristóvão, 20940-040, Rio de Janeiro, RJ, Brazil.

ABSTRACT. Roquettea decioi sp. nov. is described from Carolina, in the Brazilian state of Maranhão. It is the seventh species in Roquettea Mello-Leitão, 1931 and the eighth species of Opiliones recorded from the state. Roquettea decioi sp. nov may be characterized by ocularium low, with median depression, pedipalpal tibia without pseudo-finger forming chela and massive divergent protuberances on scutal area III.
\end{abstract}

KEY WORDS. Amazonia; Arachnida; Grassatores; harvestmen; Laniatores; Neotropics.

The harvestman fauna of the North Brazilian transition Amazonic Forest/Cerrado is poorly known. Roewer (1928) described five species of Cosmetidae from "Nord-Brasilien: Sierra da Cinta", which Kury (2003) interpreted as being the mountain ridge Serra da Cinta, located in the state of Maranhão. All records from this locality need confirmation. After that, only two species of Stygnidae have been recorded from Maranhão (Pinto-da-Rocha 1997, Pinto-da-Rocha \& Carvalho 2009).

There has been a recent surge of activity in the taxonomy of Roquettea, which was monotypic and neglected for 80 years. Five new species with bizarre-shaped scutal armature and/or unique ocularium have been described from northern Brazil (Ferreira \& Kury 2010, Kury \& Ferreira 2012).

A few specimens of Cosmetidae from Carolina, almost in the boundary of Maranhão with Tocantins were recently made available for study. They have been collected in Maranhão, the transitional Amazonic Forest/Cerrado region, by ichthyologist Décio F. Moraes Jr from the Museu Nacional, Rio de Janeiro (MNRJ), and one of them is a representative of a new species of Roquettea Mello-Leitão, 1931, which is described below, being the eighth species of Opiliones recorded from the state and the first record of Roquettea from the state.

\section{MATERIAL AND METHODS}

Descriptions of colors use the standard names of the 267 Color Centroids of the NBS/ISCC Color System (http:// people.csail.mit.edu/jaffer/Color/Dictionaries\#nbs-iscc) as described in KURY \& ORRICO (2006). All measurements are in millimeters. Measurements of the appendages were taken only from the femur and tibia, which are the long and variable podomeres. Other podomeres are uniformly short in the family. Description standards follow FerreIRA \& Kury (2010).

Abbreviations used: (CL) carapace length, (CW) carapace width, (AL) abdominal scutum length, (AW) abdominal scutum width, (Tr) trochanter, (Fe) femur, (Pa) patella, (Ti) tibia, (Mt) metatarsus, (Ta) tarsus.

Tarsal formula: numbers of tarsomeres are presented in order from tarsus I to IV, when an individual count is given, the order is from left to right side (figures in parentheses denote number of tarsomeres only in the distitarsus I-II).

\section{TAXONOMY}

\section{Roquettea Mello-Leitão, 1931}

Roquettea Mello-Leitão, 1931: 117; Kury, 2003: 89 (catalogue); Ferreira \& Kury, 2010: 699 (detailed diagnosis, revision, see this for exhaustive literature); Kury \& Ferreira, 2012: 36 (key to species).

Tetracyphus Sørensen, 1932: 312. Synonymy established by Mello-Leitão, 1933: 105.

Included species. Roquettea carajas Kury \& Ferreira, 2012, Roquettea decioi sp. nov., Roquettea jalapensis Ferreira \& Kury, 2010, Roquettea peba Kury \& Ferreira, 2012, Roquettea scrotalis Ferreira \& Kury, 2010, Roquettea singularis Mello-Leitão, 1931 (type species), Roquettea taurina Ferreira \& Kury, 2010.

\section{Roquettea decioi sp. nov. \\ Figs 1-7}

Type data. Male holotype (MNRJ 7785), BrazIL, Maranhão: Carolina (Parque da Pedra Caída, in humid canyon amidst the Cerrado, ca. -7.03, -47.47, $170 \mathrm{~m}$ ).

Diagnosis. Distinguished from $R$. singularis and $R$. scrotalis by having two pairs of protuberances (Fig. 3) on areas I and III (instead of a single column topped with globoid apophyses). Distinguished from $R$. peba and $R$. taurina by having ocularium low, with median depression (Figs 2 and 3) (instead of heavily built and horn-like projected). Distinguished from $R$. jalapensis 


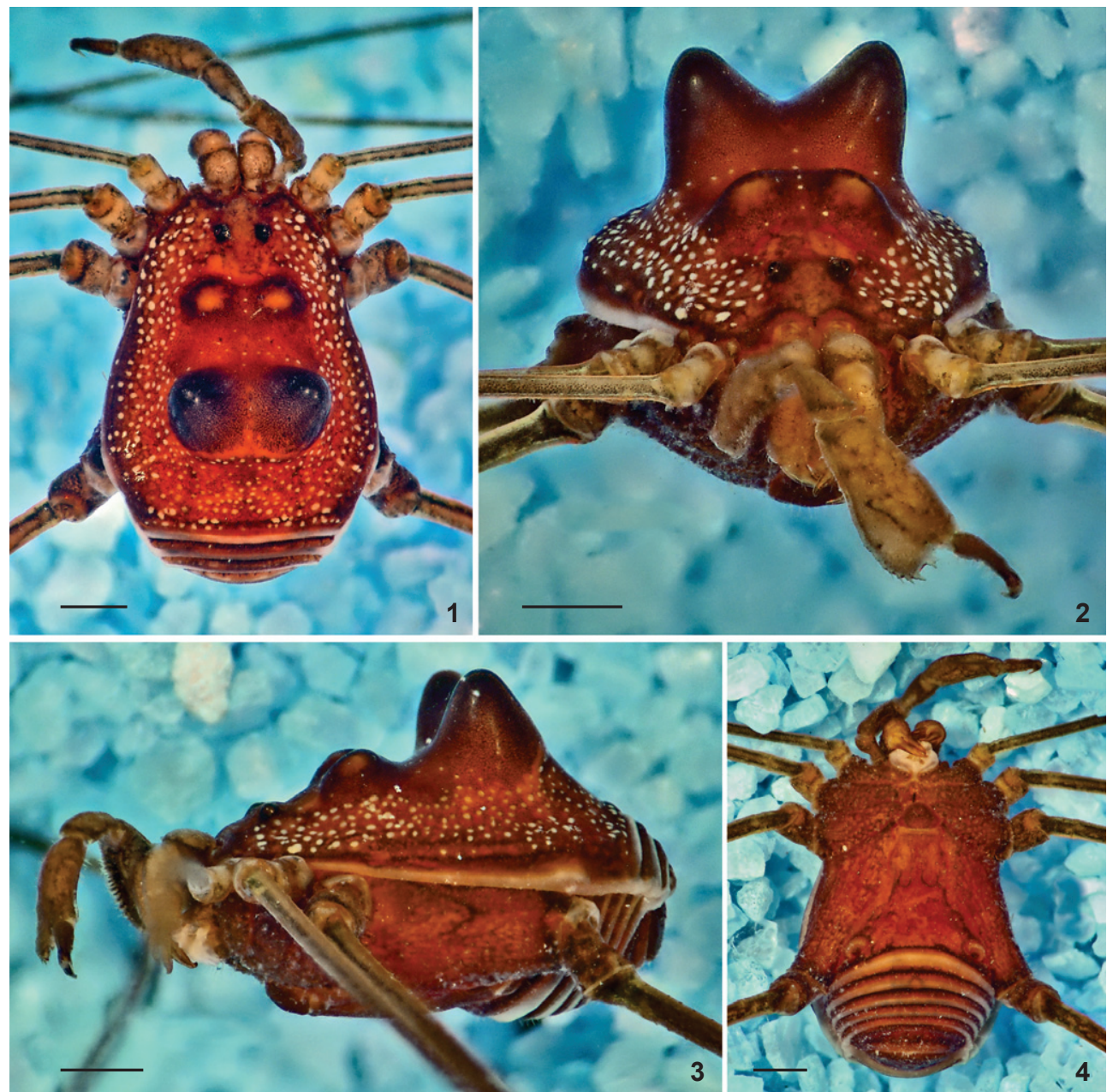

Figures 1-4. Roquettea decioi sp. nov., male holotype (MNRJ 7785), habitus: (1) dorsal view; (2) frontal view; (3) lateral view; (4) ventral view. Scale bars: $1 \mathrm{~mm}$.

by cheliceral bulla armed posteriorly with several small acuminate teeth (Fig. 7) (instead of a few large blunt apophyses); by having a pair of mounds on scutal area I (instead of unarmed) and by having huge, erect, very thick protuberances on area III (instead of normal spines leaned backwards). Most similar to R. carajas in the dentition of the cheliceral bulla (Fig. 7) and the presence of two pairs of non-spiniform scutal protuberances on areas I and III, anterior low, posterior high (Figs 2 and 3). Distinguished from $R$. carajas by 1) protuberances of area I more defined as two mounds (instead of sprawled); 2) protuberances of area III even more massive, fused at base and clearly divergent (instead of not fused, parallel); 3) white dots of scutum not forming $\mathrm{X}$ between protuberances (instead of with clear X-pattern); 4) pedipalpal tibia (Fig. 5) with minimal ectal-apical expansion (instead of pseudo-finger expansion opposed to tarsus, forming a rudimentary chela).
Description, male holotype. Measurements. CL: 1.47, CW: 2.98, AL: 3.95, AW: 4.20. Main appendage measurements in Table I. Dorsum. Dorsal scutum pyriform in dorsal view (type beta sensu KuRY et al. 2007, Fig. 1), scutal grooves almost entirely effaced, leaving areas barely recognizable. Cheliceral sockets small and shallow (Figs 1 and 2). Ocularium small and depressed

Table I. Appendage measurements of male holotype of Roquettea decioi sp. nov.

\begin{tabular}{lcc}
\hline Appendage & Femur & Tibia \\
\hline Pedipalpus & 1.5 & 1.8 \\
Leg I & 6.3 & 3.5 \\
Leg II & 14.2 & 9.7 \\
Leg III & 9.9 & 5.6 \\
Leg IV & 14.1 & 9.8 \\
\hline
\end{tabular}


(Figs 2 and 3). Outline of scutum in lateral view not bulged. Scutal area I armed with pair of convex protuberances roughly concolorous with background, but with darker base, area III armed with pair of extremely swollen and very high paramedian blunt conical processes fused at base and divergent, darker than background (Figs 1-3), elsewhere unarmed, with overall very fine granulation. Venter (Fig. 4). Coxae I-III transverse, parallel to each other, small. Coxa III connected to II and IV by tubercular bridges. Coxa IV greatly elongate. Coxae I to IV, stigmatic area and genital operculum finely granular. Genital operculum subtriangular rounded. Free sternites with transverse row of granules. Stigmatic area Y-shaped, strongly concave posteriorly, stigmata large and partially hidden by fold of tegument. Chelicera. Hand not swollen. Basichelicerite short, with wellmarked bulla. Antero-mesal corner of bulla with two setiferous tubercles. Posterior and ectal margins of bulla (Fig. 7) fringed with many small acuminate teeth. Pedipalpus. Usual cosmetid type. Femur compressed, strongly convex dorsally in lateral view, dorsal edge armed with three setiferous tubercles atop the most convex part, ventral edge armed with row of 11 small blunt teeth (Fig. 6). Tibia with moderate ectal-apical expansion fringed by five setiferous tubercles (Fig. 5). Tarsus slightly procurved and tapered, very elongate and slender, with ventro-distal and ventroectal rows of setiferous tubercles (Fig. 5). Legs. Trochanter I with strong anterior and posterior apophyses, visible dorsally beside scutum. Legs I-IV elongate, all segment unarmed, femora straight. Tarsal process on posterior tarsi well-developed, claws III-IV clearly pectinate. Tarsal formula: $8(3)-8(3) / 15(3)-16(3) / 9-9 /$ 11 - 11. Color (in alcohol). Body background Deep Reddish Orange (36), with numerous rounded Pinkish White (9) spots arranged in U on scutum, darker Deep Reddish Brown (41) mottling, especially around protuberance of area I, and all of protuberances of area III. Appendages Strong Reddish Orange (35), with dense darker reticle. Venter Deep Reddish Orange (36), with muck darker Deep Reddish Brown (41) mottling. Free sternites Deep Reddish Brown (41). Tibiae and metatarsi I-IV with numerous light rings, less clear on leg I. Genitalia. Penis lost during the clearing process.

Etymology. The specific epithet, decioi, honors my friend Décio Ferreira de Moraes Júnior, who found the holotype. Despite being an ichthyologist, Décio constantly keeps an eye out for arachnids.

\section{DISCUSSION}

Even with the scarcity of specimens in collections (KURY \& FERREIRA 2012), the described diversity of Roquettea is steadily increasing (from only one species known up to 2010 to seven species currently recognized). This may also be a result of their conspicuous habitus, which causes them stand out from species in other groups, and makes them easier to spot than other cosmetids.

I have given considerable thought as to whether or not to describe this species after the loss of the penis. The descrip-

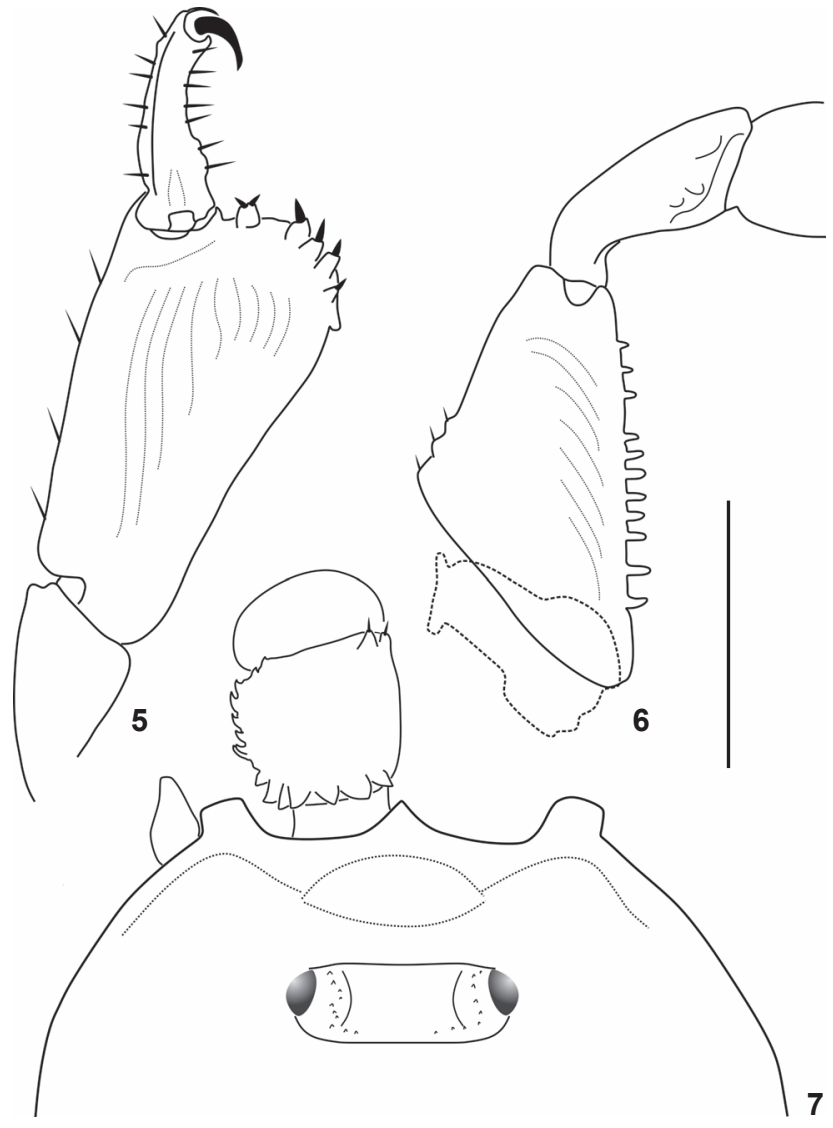

Figures 5-7. Roquettea decioi sp. nov., male holotype (MNRJ 7785): (5) left pedipalpus, tibia-tarsus, ventral view; (6) same, femur-patella, mesal view; (7) left chelicera and carapace, dorsal view. Scale bars: $1 \mathrm{~mm}$.

tion of new species without a characterization of this structure is below the current standards for Opiliones, mainly because characters of the male genitalia are important for establishing relationships. Despite these considerations, I have decided to describe the new species for the following reasons: first, all other species of Roquettea are adequately known and have already been reviewed and compared; second, the bizarre dorsal structures of males are so striking that recognition of any species is easy; third, and most importantly, the fauna of Opiliones of the state of Maranhão is so scarcely known that any addition to it is important. In the future, if more specimens of $R$. decioi are collected, I am confident that $R$. decioi can be identified with confidence and information about the penis structure can be easily added.

All species of Roquettea are distributed along a north-south ribbon more or less coinciding with the Tocantins River watershed (Fig. 8, Table II). All species but $R$. carajas occur below 500 $\mathrm{m}$ elevation. Three of the species ( $R$. singularis, $R$. decioi and $R$. taurina) occur on the Tocantins River banks in three different 


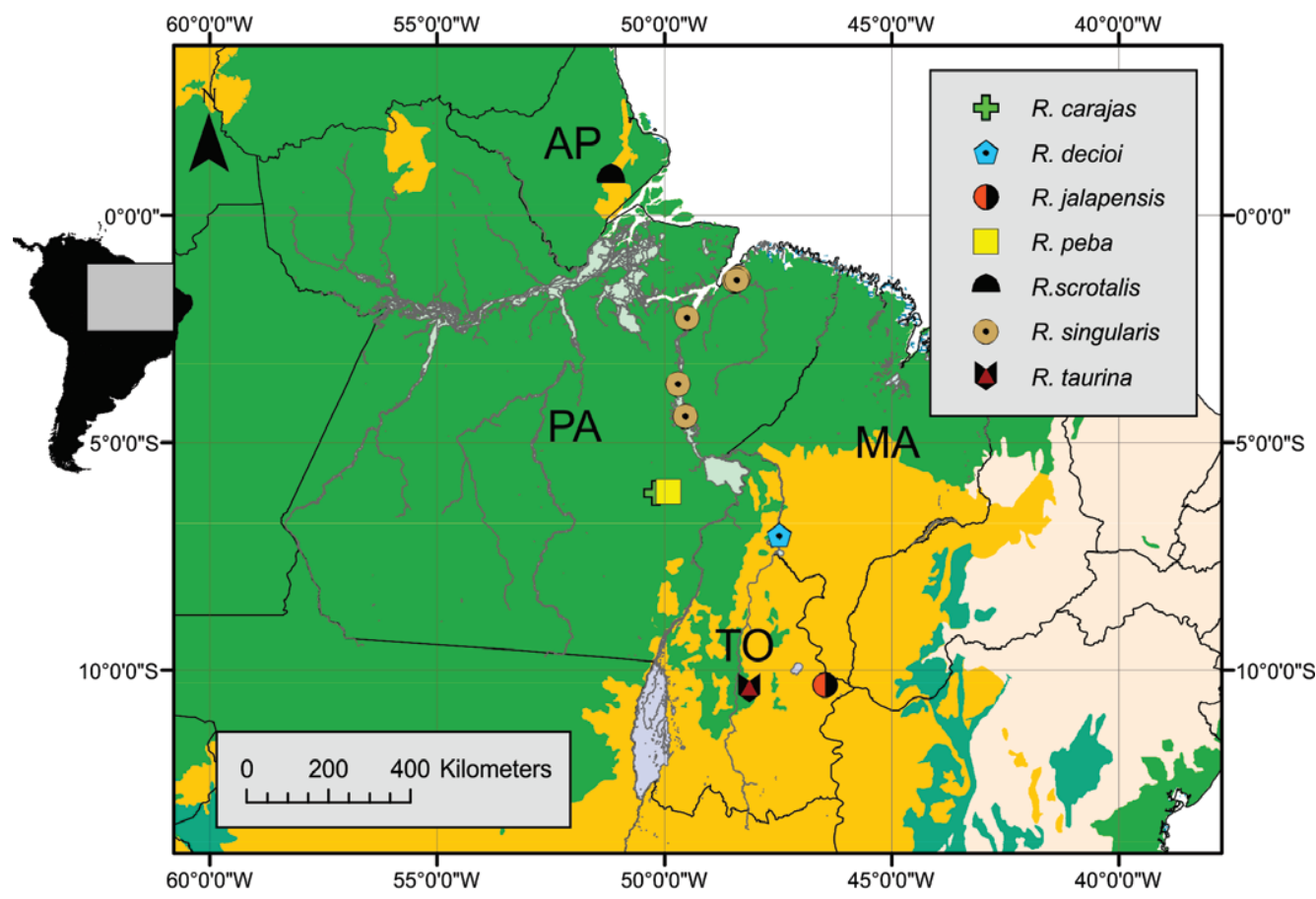

Figure 8. Northern-northeastern Brazil, showing the distribution of the seven species of Roquettea. Black outlines are Brazilian states. (AP) Amapá, (MA) Maranhão, (PA) Pará, (TO) Tocantins. Colored backgrounds are WWF biomes, from left: broadleaf forest, cerrado and caatinga.

Table II. Recorded distribution of species of Roquettea.

\begin{tabular}{llrrrl}
\hline \multicolumn{1}{c}{ Species } & Locality & Latitude & Longitude & Altitude & \multicolumn{1}{c}{ WWF Eco-region } \\
\hline R. carajas & Carajás & -6.1000 & -50.1800 & 700 & Xingu-Tocantins-Araguaia moist forests (NT0180) \\
R. decioi & Carolina & -7.0300 & -47.4700 & 170 & Transition: Mato Grosso seasonal forests (NT0140)/Cerrado (NT0704) \\
R. jalapensis & Jalapão & -10.3342 & -46.4710 & 472 & Cerrado (NT0704) \\
R. peba & Parauapeba & -6.0673 & -49.9095 & 160 & Mato Grosso seasonal forests (NT0140) \\
R. scrotalis & Ferreira Gomes & 0.8600 & -51.1800 & 7 & Transition: Uatuma-Trombetas moist forests (NT0173)/Guyanan savanna (NT0707) \\
R. singularis & Cametá & -2.2500 & -49.5000 & 150 & Tocantins/Pindaré moist forests (NT0170) \\
R. singularis & Tucuruí & -3.7000 & -49.7000 & 42 & Tocantins/Pindaré moist forests (NT0170) \\
R. singularis & Ananindeua & -1.3656 & -48.3722 & 20 & Tocantins/Pindaré moist forests (NT0170) \\
R. singularis & Belém & -1.4300 & -48.4600 & 40 & Tocantins/Pindaré moist forests (NT0170) \\
R. singularis & Utinga & -1.4166 & -48.4105 & 37 & Tocantins/Pindaré moist forests (NT0170) \\
R. singularis & I. Tocantins & -4.4167 & -49.5333 & 70 & Tocantins/Pindaré moist forests (NT0170) \\
R. taurina & Taquaruçu & -10.3942 & -48.1323 & 431 & Mato Grosso seasonal forests (NT0140) \\
\hline
\end{tabular}

Brazilian states. Roquettea species occur in moist broadleaf forests ( $R$. singularis, $R$. carajas and $R$. peba), but also in the contact borders of forest and cerrado ( $R$. decioi, $R$. taurina) or even well within the cerrado (R. jalapensis). In the latter cases they were found only in humid riparian forests amidst the dry cerrado. As the same humid forest present in Pará extends into the northern half of the state of Maranhão, Roquettea is expected to be found there as well.

\section{ACKNOWLEDGEMENTS}

This study has been supported by grant \# 562149/2010-4 (PROTAX - OPESC project) and scholarship \# 302116/2010-9 (PQ - AMMA project) from the Conselho Nacional de Desenvolvimento Científico e Tecnológico (CNPq). Décio F. de Moraes Júnior (MNRJ) has for many years contributed to the knowledge of South American arachnids, including the discovery of this species. 


\section{LITERATURE CITED}

Ferreira, C.P. \& A.B. Kury. 2010. A review of Roquettea, with description of three new Brazilian species and notes on Gryne (Opiliones, Cosmetidae, Discosomaticinae). Zoological Science 27: 697-708.

KurY, A.B. 2003. Annotated catalogue of the Laniatores of the New World (Arachnida, Opiliones). Revista Ibérica de Aracnología 1: 1-337.

Kury, A.B. \& C.P. Ferreira. 2012. Two new species of Roquettea Mello-Leitão, 1931 from northern Brazil (Opiliones: Laniatores: Cosmetidae), Zootaxa 3328: 35-46.

Kury, A.B. \& V.G.D. Orrico. 2006. A new species of Lacronia Strand, 1942 from the highlands of Rio de Janeiro (Opiliones, Gonyleptidae, Pachylinae). Revista Ibérica de Aracnologia 13: 147-153.

Kury, A.B.; O. Villarreal-M. \& C.S. Costa. 2007. Redescription of the type species of Cynorta Koch, 1839 (Arachnida, Opiliones, Cosmetidae). The Journal of Arachnology 35 (2): 325-333.
Mello-Leitão, C.F. DE. 1931. Quatro novos Opiliões. Boletim do Museu Nacional 7 (2): 115-118.

Mello-Leitão, C.F. DE. 1933. Notas sobre os opiliões do Brasil descritos na obra póstuma de Sörensen: "Descriptiones Laniatorum". Boletim do Museu Nacional 9 (1): 99-114.

PINTO-DA-Rocha, R. 1997. Systematic review of the Neotropical family Stygnidae (Opiliones, Laniatores, Gonyleptoidea). Arquivos de Zoologia 33 (4): 163-342.

Pinto-da-Rocha, R. \& L.S. Carvalho. 2009. A new species of Sickesia (Laniatores: Stygnidae: Opiliones) and new records for the State of Piauí, Brazil. Zoologia 26 (2): 337-342.

RoEWER, C.F. 1928 [1927]. Weitere Weberknechte II. (2. Ergänzung der Weberknechte der Erde, 1923). Abhandlungen der Naturwissenschaftlichen Verein zu Bremen 26 (3): 527632.

SøRENSEN, W.E. 1932. Descriptiones Laniatorum (Arachnidorum Opilionum Subordinis). Opus posthumum recognovit et edidit Kai L. Henriksen. Det Kongelige Danske Videnskabernes Selskabs skrifter, Copenhagen, series 9, 3 (4): 197-422.

Submitted: 25.II.2013; Accepted: 14.VIII.2013.

Editorial responsibility: Antonio D. Brescovit 